\title{
Eosinophilic Gastroenteritis Associated with Rheumatoid Arthritis
}

\author{
Eozinofilik Gastroenterit ile Romatoid Artrit Birlikteliği
}

\author{
Fatma PAKSOY, ${ }^{1}$ Turgay ULAŞ, ${ }^{2}$ Esat NAMAL, ${ }^{3}$ Emine GÜLTÜRK, ${ }^{4}$ Timuçin AYDOĞAN,,${ }^{5}$ Fatih BORLU 6 \\ ${ }^{1}$ Department of Oncology, Dr. Abdurrahman Yurtaslan Oncology Training and Research Hospital, Ankara, Turkey; \\ ${ }^{2}$ Department of Internal Medicine, Medical Faculty of Harran University, Şanliurfa, Turkey; \\ ${ }^{3}$ Department of Oncology, Medical Faculty of Bilim University, İstanbul, Turkey; \\ ${ }^{4}$ Department of Hematology, İstanbul University Medical Faculty of Cerrahpaşa, İstanbul, Turkey; \\ ${ }^{5}$ Department of Gastroenterology, Medical Faculty of Harran University, Şanliurfa, Turkey; \\ ${ }^{6}$ Department of Internal Medicine, Şişli Etfal Training and Research Hospital, İstanbul, Turkey
}

Objectives: In this article we evaluated the relationship
between rheumatoid arthritis and eosinophilic gastroenteritis.

Patients and methods: A 71-year-old female patient with a diagnosis of rheumatoid artritis was admitted to our clinic with gastrointestinal symptoms and peripheral eosinophilia. We examined the patient via gastrointestinal endoscopy, ultrasonography, computed tomography, stool analysis, and biochemical analysis.

Results: Gastrointestinal endoscopy revealed esophageal dysmotility, pangastritis, and duedonal erythema. Histopathologic examinations revealed subacute and chronic inflammation with dense eosinophilic infiltration. Stool analyses were negative for fat, parasites, and other pathogens. The results for ultrasonograpy and computed tomographies were normal.

Conclusion: This brief report showed us the importance of conducting further analysis when a patient with rheumatoid arthritis presents with peripheral eosinophilia and gastrointestinal discomfort. It also represents the possible coexistence of rheumatoid arthritis and eosinophilic gastroenteritis without an apparent etiology.

Key words: Eosinophilia; gastrointestinal involvement; rheumatoid arthritis.

Eosinophilic gastroenteritis (EG) is a rare gastrointestinal disorder that can present with various gastrointestinal manifestations, depending on the
Amaç: Bu yazıda, romatoid artrit ile eosinofilik gastroenterit arasındaki ilişki değerlendirildi.

Hastalar ve yöntemler: Yetmiş bir yaşında romatoid artrit tanılı kadın hasta gastrointestinal semptomlar ve periferik eosinofili ile kliniğimize başvurdu. Hasta; gastrointestinal endoskopi, ultrasonografi, bilgisayarlı tomografi ve dışkı analizleri gibi biyokimyasal tetkikler ile incelendi.

Bulgular: Gastrointestinal endoskopide özofageal dismotilite, pangastrit ve duodenumda eritem görüldü. Histopatolojik incelemede yoğun eosinofilik infiltrasyonun eşlik ettiği subakut ve kronik enflamasyon tespit edildi. Dışkı testleri yağ, parazit ve diğer patojenler açısından negatif idi. Ultrasonografi ve bilgisayarlı tomografi sonuçları normal bulundu.

Sonuç: Bu kısa rapor bize romatoid artritli hastalarda periferik eosinofili ve gastrointestinal semptomlar varlığında gastrointestinal sisteme yönelik ileri incelemeler yapılmasının önemini göstermiştir. Aynı zamanda romatoid artritli hastalarda nedeni belli olmasada eosinofilik gastroenteritin eşlik edebileceğini de göstermiştir.

Anahtar sözcükler: Eozinofili; gastrointestinal tutulum; romatoid artrit.

specific site of the affected gastrointestinal tract and specific layer of the affected gastrointestinal wall. The pathogenesis and etiology of EG remain

\footnotetext{
Received: January 26, 2011 Accepted: March 20, 2011

Correspondence: Turgay Ulaş, M.D. Harran Üniversitesi Tıp Fakültesi İç Hastalıkları Anabilim Dalı, 63300 Şanlıurfa, Turkey.

Tel: +90 414 - 3183027 e-mail: turgayulas@yahoo.com

Presented at the $10^{\text {th }}$ Congress of Internal Medicine, October 15-19, 2008, Antalya, Turkey.

(c2011 Turkish League Against Rheumatism. All rights reserved.
} 
unclear. Diagnostic criteria include demonstration of eosinophilic infiltration of the bowel wall, lack of evidence of extra-intestinal disease, and exclusion of various disorders that could mimic a similar condition. This rare disease should be considered during the differential diagnosis of unexplained gastrointestinal symptoms, especially when they are associated with peripheral eosinophilia. ${ }^{[1]}$

Rheumatoid arthritis (RA) is a chronic disease that can cause irreversible joint damage and significant disability. Even with a prevalence of only $1 \%$, there is a considerable impact on the community. Diagnosis is based on a combination of clinical and laboratory features. Patients typically present with a symmetrical polyarthritis of the small joints of the hands and feet accompanied by early morning stiffness and possible occasional, constitutional symptoms. ${ }^{[2]}$

The relationship between EG and $\mathrm{RA}$ is, however, unclear. Until now, there have only been three published reports in the literature concerning their coexistence, but there was no clarification to explain it..$^{[3-5]}$ Therefore, we aimed to present the coexistance of EG and RA in relation to its contribution to the literature while also seeking to determine whether it can be used in the detection of overlooked diseases.

\section{CASE REPORT}

A 71-year-old female presented with a history of generalized aches, nausea, upper abdominal tenderness and swelling along with pain and limited movement of the left knee. Her constitutional symptoms had worsened over the previous year, and she had lost eight pounds. She had used ranitidine and omeprazole without benefit. She had an eight-year history of seropositive RA, and her medications had included methotrexate and nonsteroidal antiinflammatory drugs (NSAIDs), but she rarely took the NSAIDS. She had no personal or family history of allergic reactions. A clinical examination revealed a mildly distended, tender abdomen, signs of active arthritis of the left knee joint, and chronic deformities of the hands caused by RA. Stool samples were negative for ova, parasites, and common pathogens. A complete blood count revealed a white blood cell (WBC) count of $7360 / \mathrm{mm}^{3}$ with an eosinophil count of $23.2 \%$ (normal 0 to $4 \%$ ). The erythrocyte sedimentation rate (ESR) was 64 first hour, and the C-reactive protein level was $161 \mathrm{~g} / \mathrm{dl}$. Other laboratory tests and tumor markers were unremarkable. Computed tomography (CT) scans and ultrasonography of the abdomen were normal. Esophagogastroduodenoscopy (EGD) revealed esophageal dysmotility. Pangastritis and erythema of the duodenal bulb were also noted. Histological examination and biopsies from the gastric antrum and duodenum demonstrated subacute and chronic inflammation with distinct eosinophilic infiltration of the submucosa and muscularis. Therefore, the diagnosis of EG was confirmed. Because of the symptoms of RA and EG, we started treatment with prednisone $60 \mathrm{mg} /$ day. Her eosinophil count normalized after the steroid treatment. However, her abdominal pain recurred, and she reported worsening nausea, postprandial fullness, and bloating. For this reason, sodium cromoglycate $200 \mathrm{mg}$ three times a day (TID) was added to her treatment with modest improvement of her symptoms. However, during hospitalization follow-up, she developed nosocomial pneumonia and died due to sepsis.

\section{DISCUSSION}

Eosinophilic gastroenteritis is a rarely diagnosed inflammatory bowel disease that is defined by the presence of nonspecific gastrointestinal symptoms, histologic infiltration of the gastrointestinal wall by eosinophilic granulocytes in a diffuse or segmentary manner, and exclusion of parasitic and extraintestinal diseases. $^{[6]}$ Although the etiology of eosinophilic gastroenteritis is still undefined, autoimmune mechanisms may play an important role in the development of this disease. ${ }^{[7]}$

Rheumatoid vasculitis is a relatively uncommon complication of RA. It shows a wide variety of extraarticular features, including skin and neurologic involvement, but rarely shows gastrointestinal involvement. Several studies suggest that RA may affect the gastrointestinal system. Intestinal ischemia, rectal bleeding, hemorrhage, multiple small bowel ulcerations, obstruction, infarction, and perforation are seen in the course of RA. A pathological examination of these studies showed multiple lesions of the small intestine were caused by rheumatoid vasculitis. Also, histologic changes were characterized by partial or complete loss of superficial epithelium, lymphocytes, plasma cells, granulocytes, and the presence of vasculitic lesions. ${ }^{[8-12]}$ In these reports, no eosinophilic cells were seen in the histologic examination; however, in our case, we detected distinct eosinophilic infiltration on the bowel wall.

While the association between RA and peripheral blood eosinophilia is well recognized, the link 
between tissue eosinophilia and RA is less well established. Eosinophilic pneumonia, eosinophilic fasciitis, hypereosinophilic syndrome, and cutaneous eosinophilic vasculitis have been described in patients with RA. ${ }^{[3]}$ In our patient, there was no evidence of other systemic tissue eosinophilic infiltration outside the gastrointestinal tract.

Steroids are the mainstay of treatment in EG, and about $90 \%$ of patients respond to this therapy. Patients with serosal disease usually show a dramatic response to steroids. Sodium cromoglycate is a mast cell stabilizer that prevents release of toxic mediators such as histamine, platelet activating factors, and leukotrienes from mast cells. Ketotifen is similar to sodium cromoglycate in its biological profile and may be useful in some cases. The elimination of presumed dietary articles is unhelpful in most cases. Successful treatment of EG with montelukast, a leukotriene modifier, has been reported. Suplatast tosilate is a new IL-4 and IL-5 inhibitor which has proven to be effective in treating asthma and has been reported to be useful in the treatment of EG. ${ }^{[13]}$ In our case, the patient was given a steroid and sodium cromoglycate. There was no benefit of the steroid therapy, and no response was observed to the sodium cromoglycate because of early death due to sepsis.

In conclusion, EG is a blood disorder which damages the mucosa of the gastrointestinal tract, and gastrointestinal involvement occurs in patients with RA due to vasculitis. Symptoms are related to the layer of bowel mucosa involved. To our knowledge, there have only been three published reports on clinically manifested eosinophilic enterocolitis in a patient with $\mathrm{RA}^{[3-5]}$ and the relationship between EG and RA is unclear. It is a rare and heterogeneous disease that is probably misdiagnosed in clinical practice because it encounters a high degree of suspicion. Peripheral eosinophilic counts should be performed in RA patients with nonspecific abdominal complaints. When these counts are elevated, an endoscopic investigation of the upper gastrointestinal tract should be performed, and biopsies of both abnormal and normal mucosa should be taken.

\section{Declaration of conflicting interests}

The authors declared no conflicts of interest with respect to the authorship and/or publication of this article.

\section{Funding}

The authors received no financial support for the research and/or authorship of this article.

\section{REFERENCES}

1. Hsu YQ, Lo CY. A case of eosinophilic gastroenteritis. Hong Kong Med J 1998;4:226-228.

2. Ngian GS. Rheumatoid arthritis. Aust Fam Physician 2010;39:626-8.

3. Ng WF, Cohen P, Hepburn A, Hamdulay S, Carpani M, Mason JC. A case of eosinophilic enteritis and rheumatoid arthritis. Rheumatology (Oxford) 2005 ;44:1585-6.

4. Schwake L, Stremmel W, Sergi C. Eosinophilic enterocolitis in a patient with rheumatoid arthritis. J Clin Gastroenterol 2002;34:487-8.

5. Medina Pérez M, Novales Vasco G, Medina Pérez A, Oliva Mompeán F. Eosinophilic gastroenteritis associated with rheumatoid arthritis. Its presentation as acute abdominal pain. Rev Esp Enferm Dig 1997;89:143-4. [Abstract]

6. Lee CM, Changchien CS, Chen PC, Lin DY, Sheen IS, Wang CS, et al. Eosinophilic gastroenteritis: 10 years experience. Am J Gastroenterol 1993;88:70-4.

7. Talley NJ, Shorter RG, Phillips SF, Zinsmeister AR. Eosinophilic gastroenteritis: a clinicopathological study of patients with disease of the mucosa, muscle layer, and subserosal tissues. Gut 1990;31:54-8.

8. Takeuchi K, Kuroda Y. Rheumatoid vasculitis with multiple intestinal ulcerations: report of a case. Ryumachi 2000;40:639-43. [Abstract]

9. Porzio V, Biasi G, Corrado A, De Santi M, Vindigni C, Viti $S$, et al. Intestinal histological and ultrastructural inflammatory changes in spondyloarthropathy and rheumatoid arthritis. Scand J Rheumatol 1997;26:92-8.

10. Marcolongo R, Bayeli PF, Montagnani M. Gastrointestinal involvement in rheumatoid arthritis: a biopsy study. J Rheumatol 1979;6:163-73.

11. Altomonte L, Zoli A, Alessi F, Ghirlanda G, Greco AV, Magarò M. Gastroenterologic aspects of connective tissue diseases. Minerva Med 1985;76:1323-9. [Abstract]

12. Kuehne SE, Gauvin GP, Shortsleeve MJ. Small bowel stricture caused by rheumatoid vasculitis. Radiology 1992;184:215-6.

13. Sheikh RA, Prindiville TP, Pecha RE, Ruebner BH. Unusual presentations of eosinophilic gastroenteritis: case series and review of literature. World J Gastroenterol 2009;15:2156-61. 